Article

\title{
Extraction of Cobalt and Iron from Refractory Co-Bearing Sulfur Concentrate
}

\author{
Junhui Xiao ${ }^{1,2,3,4, *(1)}$ and Yushu Zhang ${ }^{2,4}$ \\ 1 Sichuan Engineering Lab of Non-Metallic Mineral Powder Modification and High-Value Utilization, \\ Southwest University of Science and Technology, Mianyang 621010, China \\ 2 Institute of Multipurpose Utilization of Mineral Resources, Chinese Academy of Geological Sciences, \\ Chengdu 610041, China; fanshanping@swust.edu.cn \\ 3 Key Laboratory of Sichuan Province for Comprehensive Utilization of Vanadium and Titanium Resources, \\ Panzhihua University, Panzhihua 61700, China \\ 4 Key Laboratory of Ministry of Education for Solid Waste Treatment and Resource Recycle, \\ Southwest University of Science and Technology, Mianyang 621010, China \\ * Correspondence: xiaojunhui33@163.com; Tel.: +86-139-9019-0544
}

Received: 7 January 2020; Accepted: 4 February 2020; Published: 6 February 2020

\begin{abstract}
In this study, oxidizing roasting, segregation roasting, and magnetic separation are used to extract cobalt and iron from refractory Co-bearing sulfur concentrate. The Co-bearing sulfur concentrate containing $0.68 \% \mathrm{Co}, 33.26 \% \mathrm{Fe}$, and $36.58 \% \mathrm{~S}$ was obtained from V-Ti magnetite in the Panxi area of China by flotation. Cobalt pyrite and linneite were the Co-bearing minerals, and the gangue minerals were mica, chlorite, feldspar, and calcite in Co-bearing sulfur concentrate. The results show that cobalt is transformed from Co-pyrite and linneite to a $\mathrm{Co}_{2} \mathrm{FeO}_{4}$-dominated new cobalt mineral phase, and iron is transformed from pyrite to $\mathrm{Fe}_{2} \mathrm{O}_{3}$ and an $\mathrm{Fe}_{3} \mathrm{O}_{4}$-dominated new iron mineral phase after oxidizing roasting. Cobalt changed from $\mathrm{CoFe}_{2} \mathrm{O}_{4}$ to a new cobalt mineral phase dominated by [Co] Fe solid solution, and iron changed from $\mathrm{Fe}_{2} \mathrm{O}_{3}$ to a new iron mineral phase dominated by metal $\mathrm{Fe}$ and $\mathrm{Fe}_{3} \mathrm{O}_{4}$ after segregation roasting. Cobalt concentrate with a cobalt grade of $15.15 \%$, iron content of $71.22 \%$, and cobalt recovery of $90.81 \%$ as well as iron concentrate with iron grade of $60.06 \%$, cobalt content of $0.11 \%$, and iron recovery of $76.23 \%$ are obtained. The main minerals in the cobalt concentrate are $\mathrm{Fe},[\mathrm{Co}] \mathrm{Fe}_{2}, \mathrm{Fe}_{3} \mathrm{O}_{4}$, and $\mathrm{SiO}_{2}$, and the main minerals in the iron concentrate are $\mathrm{Fe}_{3} \mathrm{O}_{4}, \mathrm{FeO}, \mathrm{Ca}_{2} \mathrm{Si}_{2} \mathrm{O}_{4}$, and $\mathrm{Ca}_{2} \mathrm{Al}_{2} \mathrm{O}_{4}$.
\end{abstract}

Keywords: cobalt; iron; Co-bearing sulfur concentrate; roasting; magnetic separation

\section{Introduction}

The unique physical and chemical properties of cobalt make this metal an important raw material in the fields of aerospace, petrochemicals, glass manufacturing, and medicine. Cobalt plays an important role in the development of strategic emerging industries. The content of cobalt in the crust is very low, and $90 \%$ of cobalt in the crust is in a dispersed state. In nature, cobalt is mostly associated with copper, nickel, iron, and other minerals, and there is no separate cobalt deposit. Both the United States and the European Union have included cobalt in the list of key minerals and materials that affect national and regional security and future economic development. According to the research of the China Mining Federation, cobalt will become one of the nine minerals in serious shortage by 2020. China is one of the world's major producers and consumers of refined cobalt, but China's cobalt reserves only account for $1.1 \%$ of the total global reserves. A large number of cobalt raw materials rely on imports. Most of the cobalt minerals found on the earth are associated with copper sulfide ore, nickel sulfide ore, pyrite, and other minerals, and only about $2 \%$ of the global cobalt production 
comes from independent cobalt mines. According to the statistics of USGS 2019, the proven global land cobalt resources are 25 million tons and reserves are 6.88 million tons [1]. Based on the global cobalt production of 136,000 tons in 2018, the static guarantee period is 50 years. More than 120 million tons of cobalt resources have been found at the bottom of the Atlantic Ocean, the Indian Ocean, and the Pacific Ocean. Because of technical and economic reasons, these resources have not been exploited up to now. The global land cobalt resources are widely distributed. Cobalt resources mainly occur in sedimentary stratiform copper cobalt deposits in the Congo and Zambia; laterite nickel cobalt deposits in Australia, Cuba, the Philippines, and Madagascar; and magmatic nickel copper sulfide deposits in Australia, Canada, and Russia. Although cobalt ore is widely distributed, except that the bouazzer cobalt ore in Morocco is a separate cobalt ore with arsenic cobalt as the main mineral, the rest of the world's cobalt ore is produced as a co-associated mineral of copper, nickel, and other minerals. At present, only a few countries, such as the Congo, Australia, Cuba, Canada, and Russia, can use the cobalt ore economically. There are more than 100 kinds of minerals containing cobalt in nature, and more than 59 kinds of minerals contain cobalt as a basic element. However, at present, there are mainly three kinds of cobalt minerals with economic significance: arsenides, sulfides, and oxides. Common cobalt minerals in the industry include cobaltite, glaucodot, linnetie, smaltite, safflorite, and erthrite as well as asbolite and heterogenite in supergene minerals [2]. The main common cobalt minerals and their properties are shown in Table 1.

Table 1. The common cobalt minerals and their properties.

\begin{tabular}{cccccc}
\hline $\begin{array}{c}\text { Mineral } \\
\text { Species }\end{array}$ & $\begin{array}{c}\text { Mineral } \\
\text { Names }\end{array}$ & Chemical Formula & $\begin{array}{c}\text { Cobalt } \\
\text { Content } \mathbf{~ \% )}\end{array}$ & $\begin{array}{c}\text { Density } \\
\left(\mathbf{g} \cdot \mathbf{c m}^{-3}\right)\end{array}$ & $\begin{array}{c}\text { Moh's } \\
\text { Hardness }\end{array}$ \\
\hline \multirow{5}{*}{ Arsenide } & Smaltite & $\mathrm{CoAs}_{2}$ & $1.5-24$ & $6.4-6.6$ & $5.6-6$ \\
& Safflorite & $(\mathrm{Co}, \mathrm{Ni}, \mathrm{Fe}) \mathrm{As}_{2}$ & $1.3-23$ & $6.9-7.3$ & $4.5-5$ \\
& Skutterudite & $\mathrm{CoAs}(\mathrm{Co}, \mathrm{Ni}, \mathrm{Fe}) \mathrm{As}_{3}$ & $16-20$ & $6.7-6.9$ & 6 \\
& Cobaltite & $\mathrm{CoAsS}$ & $29-39$ & $5.8-6.3$ & $5.5-6$ \\
& Glaucodot & $(\mathrm{Co}, \mathrm{Fe}) \mathrm{AsS}$ & $8-18$ & $5.9-6$ & 5 \\
\hline \multirow{2}{*}{ Sulfide } & Carrollite & $\mathrm{Cu}\left(\mathrm{Co}, \mathrm{Ni}_{2} \mathrm{~S}_{4}\right.$ & $27-42$ & $4.8-5$ & 5.5 \\
& Linneite & $\mathrm{Co}_{3} \mathrm{~S}_{4}$ & $45-53$ & $4.8-5$ & 5.5 \\
\hline \multirow{5}{*}{ Oxide } & Asbolite & $\mathrm{CoO}_{2} \mathrm{MnO}_{2} \cdot 4 \mathrm{H}_{2} \mathrm{O}$ & Traces-25 & 3.1 & $2-2.5$ \\
& Erthrite & $\mathrm{Co}_{3}\left(\mathrm{AsO}_{4}\right)_{2} \cdot 8 \mathrm{H}_{2} \mathrm{O}$ & 30 & $2.9-3$ & $1.5-2.5$ \\
& Heterogenite & $\mathrm{Co}_{2} \mathrm{O}_{3} \mathrm{H}_{2} \mathrm{O}$ & $50-60$ & $4.1-4.5$ & $3-5$ \\
& Spherocobaltite & $\mathrm{CoCO}_{3}$ & $50-55$ & $4-4.1$ & 4 \\
\hline
\end{tabular}

Cobalt-sulfur concentrate is the most common raw material for industrial cobalt extraction. Pyrite is the most important sulfur-bearing mineral in cobalt sulfur concentrate. Because the cobalt-sulfur concentrate mainly contains pyrite, pyrrhotite, and some gangue minerals such as talcum, quartz, and chlorite, it is difficult to obtain separate cobalt and sulfur concentrates. Most cobalt minerals are associated with other metal minerals. At present, the main cobalt minerals to be processed include cobaltite, skutterudite, thiocopper cobalt, thiocobaltite, nickel cobalt, cobaltite, iron manganese combined cobalt, etc. The most common process to recover cobalt minerals is flotation, which also includes manual separation and gravity separation. Single cobalt minerals, such as cobaltite and thiocobaltite, can be directly obtained from cobalt concentrate by flotation; for cobalt existing in pyrite and chalcopyrite, carrier flotation is generally used, and cobalt concentrate cannot be directly obtained. Recovery of associated cobalt in V-Ti-magnetite is essentially a mixture of pyrite, pyrrhotite, cobaltite, and thiocobaltite. The recovery of valuable metals from cobalt-bearing sulfur concentrate is usually carried out by the combination of pyrometallurgy and hydrometallurgy [3-6]. For example, the main disadvantage of direct sulfuric acid roasting in the Shandong Zibo cobalt plant is that the treatment capacity is low $\left(3.0 \mathrm{t} / \mathrm{m}^{2} \cdot \mathrm{d}\right)$, and the $\mathrm{SO}_{2}$ content in the flue gas is only $4-5 \%$, which is not conducive to acid production. Aiming at the roasting leaching of cobalt sulfur concentrate with high cobalt content, low sulfur content, and a considerable amount of copper, the effects of roasting temperature, roasting 
time, additive dosage, leaching time, leaching temperature, and liquid-solid ratio were analyzed to investigate the influence of the leaching rates of copper and cobalt. After the cobalt-sulfur concentrate was mixed evenly, the temperature was raised to $620^{\circ} \mathrm{C}$ at $2.7^{\circ} \mathrm{C} / \mathrm{min}$, calcined for $3 \mathrm{~h}$, and the calcine was leached at $80^{\circ} \mathrm{C}$ with $33 \%$ slurry concentration of $30 \mathrm{~g} / \mathrm{L}$ sulfuric acid for $2 \mathrm{~h}$, the results showed leaching rates of $\mathrm{Co}$ and $\mathrm{Cu}$ of $91 \%$ and $90 \%$ respectively. The cobalt sulfur concentrate was oxidized roasted at $850-900^{\circ} \mathrm{C}$, and the cinder was mixed with some cobalt sulfur concentrate and chlorinating agent to carry out medium-temperature chlorination sulfuric acid roasting at about $650{ }^{\circ} \mathrm{C}$. This way had a high bed capacity $\left(17-18 \mathrm{t} / \mathrm{m}^{2} \cdot \mathrm{d}\right)$, but the $\mathrm{SO}_{2}$ concentration in the flue gas was only $1-2 \%$, which is difficult for acid production, and there was a certain amount of hydrogen chloride gas in the flue gas, which will lead to serious corrosion of the equipment [7-10].

There is a large amount of valuable mineral resources in the Panxi area of China, and the proven reserves of V-Ti magnetite are 10 billion tons. Among them, iron resources account for $20 \%$ of the domestic iron ore reserves, vanadium resources account for $62 \%$ of the national vanadium reserves, and titanium resources account for $90.5 \%$ of the national titanium reserves. In addition, there are 900,000 tons of cobalt, 700,000 tons of nickel, 250,000 tons of scandium, 180,000 tons of gallium, and other resources. The comprehensive utilization rate of nonferrous metal resources in the Panxi area of China is very low. Because of the low grade and scattered distribution, it is difficult to recover the sulfur and cobalt resources directly from the raw ore. Most of the associated valuable metal cobalt in V-Ti magnetite occurs in the form of pyrite, pyrrhotite, and cobaltite, and a very small amount of cobalt occurs in the form of thiocobaltite. Because the floatability difference among pyrite, pyrrhotite, cobalt nickel pyrite, and thiocobaltite is small, they basically exhibit the surface properties of pyrite minerals, so it is difficult to recover separate minerals by flotation.

At present, iron concentrate, titanium concentrate, and cobalt-bearing sulfur concentrate are obtained from V-Ti magnetite ores in the Panxi area of China by magnetic separation and flotation. In the process of flotation, cobalt enters into sulfur concentrate, which is closely related to pyrite. Generally, Co-bearing sulfur concentrate with a cobalt grade of about $0.6 \%$ can be enriched by flotation. It is difficult to further separate cobalt and sulfur using flotation or other physical beneficiation. In this paper, a technology of two-stage roasting and magnetic separation is adopted to extract cobalt and iron from the complex Co-bearing sulfur concentrate in the Panxi area of China. This will provide an important research basis for the efficient utilization of Co-bearing sulfur concentrate resources in Panxi [11-14].

\section{Materials and Methods}

\subsection{Sampling}

The Co-bearing sulfur concentrate sample was collected from a V-Ti magnetite dressing plant by flotation in the Panzhihua area of China. The Co-bearing sulfur concentrate contained Co $0.68 \%$, $\mathrm{Fe} 33.26 \%$, and S $36.58 \%$. Pyrite was the main sulfide ore. Co-pyrite and linneite were Co-bearing minerals. Gangue minerals were mica, chlorite, feldspar, calcite, etc., in the Co-bearing concentrate. The main chemical composition analysis of the sample is shown in Table 2 . The main mineral analysis of the sample is shown in Table 3, a grain-sized analysis of the sample is shown in Table 4, and the XRD analysis of the sample is shown in Figure 1.

Table 2. Main chemical composition of Co-bearing sulfur concentrate (\%).

\begin{tabular}{|c|c|c|c|c|c|c|c|c|c|c|}
\hline $\mathrm{Fe}$ & Co & $S$ & $\mathrm{CaO}$ & $\mathrm{MgO}$ & $\mathrm{Al}_{2} \mathrm{O}_{3}$ & $\mathrm{SiO}_{2}$ & Mn & $\mathrm{K}_{2} \mathrm{O}$ & $\mathrm{Na}_{2} \mathrm{O}$ & $\mathrm{TiO}_{2}$ \\
\hline 33.26 & 0.68 & 36.58 & 5.06 & 3.67 & 8.63 & 8.26 & 0.06 & 0.68 & 0.23 & 2.06 \\
\hline
\end{tabular}


Table 3. Main minerals composition of Co-bearing sulfur concentrate (\%).

\begin{tabular}{cccccccc}
\hline Pyrite & Linneite & Co-Pyrite & Mica & Chlorite & Calcite & Feldspar & Other Minerals \\
\hline 71.65 & 3.68 & 2.65 & 2.64 & 3.36 & 8.22 & 4.68 & 3.12 \\
\hline
\end{tabular}

Table 4. Grain-sized analysis of Co-bearing sulfur concentrate.

\begin{tabular}{cccccccc}
\hline \multirow{2}{*}{ Fractions (mm) } & \multirow{2}{*}{ Productivity (\%) } & \multicolumn{3}{c}{ Grade (\%) } & \multicolumn{4}{c}{ Distribution Rate (\%) } \\
\cline { 3 - 8 } & & Fe & Co & S & Fe & Co & S \\
\hline$-0.28 \sim+0.154$ & 10.68 & 30.27 & 0.56 & 32.97 & 9.72 & 8.80 & 9.63 \\
$-0.154 \sim+0.1$ & 24.15 & 34.59 & 0.72 & 37.86 & 25.12 & 25.57 & 25.00 \\
$-0.1 \sim+0.074$ & 36.78 & 33.18 & 0.68 & 37.22 & 36.69 & 36.78 & 37.42 \\
$-0.074 \sim+0.045$ & 17.25 & 33.69 & 0.65 & 35.84 & 17.47 & 16.49 & 16.90 \\
$-0.045 \sim+0.038$ & 6.36 & 34.02 & 0.78 & 36.36 & 6.51 & 7.30 & 6.32 \\
$-0.038+0$ & 4.78 & 31.27 & 0.72 & 36.21 & 4.49 & 5.06 & 4.73 \\
Totals & 100.00 & 33.26 & 0.68 & 36.58 & 100.00 & 100.00 & 100.00 \\
\hline
\end{tabular}

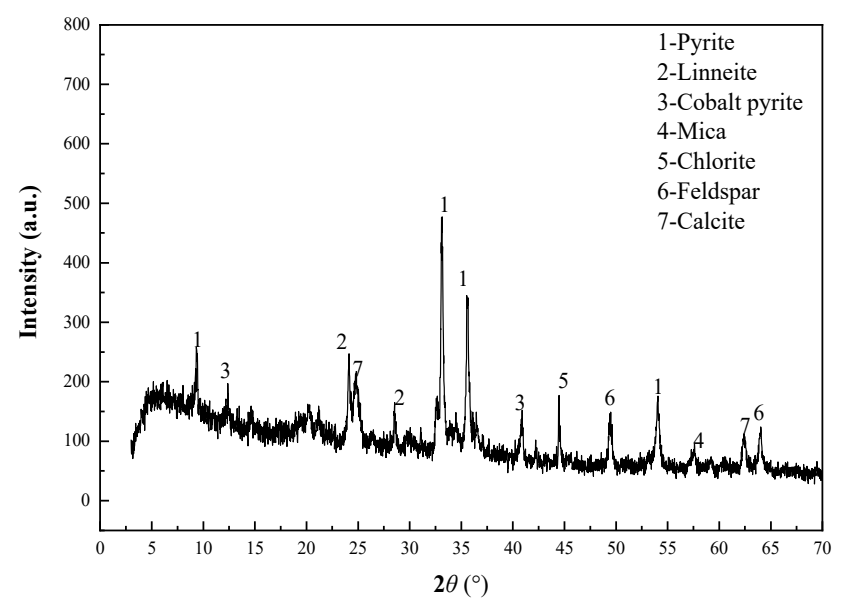

Figure 1. X-ray diffraction (XRD) diffractogram of Co-bearing sulfur concentrate.

\subsection{Chemical Reagent and Equipment}

The main chemical reagents used in this test were calcium chloride and sodium chloride with analytical purity from Guangzhou Chemical Regent, Co., Ltd., Guangzhou China. The coke from Shanxi Coking Coal Group Co. Ltd. (Taiyuan, China) was crushed and divided into five particle sizes of $-1 \mathrm{~mm},-0.8 \mathrm{~mm},-0.6 \mathrm{~mm},-0.4 \mathrm{~mm}$, and $-0.2 \mathrm{~mm}$ as reducing agents in the process of segregation roasting. The entire quality analysis of coke is shown in Table 5 .

Table 5. The entire quality analysis of coke. $\mathrm{M}_{\mathrm{ad}}$ : Air drying base content. $\mathrm{A}_{\mathrm{d}}$ : ash content. $\mathrm{V}_{\mathrm{daf}}$ : Volatile content. $\mathrm{FC}_{\mathrm{d}}$ : Fixed Carbon content.

\begin{tabular}{ccccc}
\hline $\mathbf{M}_{\mathbf{a d}}$ & $\mathbf{A}_{\mathbf{d}}$ & $\mathbf{F C}_{\mathbf{d}}$ & $\mathbf{V}_{\text {daf }}$ & Characteristic of Char Residue \\
\hline 0.44 & 2.05 & 95.68 & 1.08 & 2 \\
\hline
\end{tabular}

The main equipment used in the experiment included an electric atmosphere tube furnace (Model: SX-6-16, Changsha Kehui Furnace Technology Co., Ltd., Changsha, China), muffle furnace $\left(\leq 1300{ }^{\circ} \mathrm{C}\right.$, Shanghai Shiyan Electric Furnace Co., Ltd. Shanghai, China), cone ball mill (XMQ- $\Phi 240 \times 90 \mathrm{~mm}$, Jilin Exploration Machinery Factory, Changchun, China), Disc grinder ( $\Phi 300 \times 150$ mm, Jilin Exploration Machinery Factory, Changchun, China), drying box (Shanghai Shiyan Yan Electric Furnace Co., Ltd. Shanghai China), and vacuum filter ( $\Phi$ 300, Southwest Chengdu Experimental Equipment Co., Ltd. Chendu, China). 


\subsection{Oxidizing Roasting Test}

Oxidizing roasting tests were conducted in an electric atmosphere tube furnace, and Co-bearing sulfur concentrate was put into a corundum dry pot and put into the electric atmosphere tube furnace. The temperature was set to $600-1000{ }^{\circ} \mathrm{C}$ in an oxygen atmosphere. When the temperature of the electric atmosphere tube furnace rose to the set temperature, timing started. After roasting for $1-3 \mathrm{~h}$, the oxygen supply was stopped, and the power supply was turned off. Meanwhile, the oxygen-passing tube was pulled out, and the roasting product was taken out for cooling, manual crushing, and grinding to $<0.100 \mathrm{~mm}$ for segregation roasting. The oxidizing roasting conditions were confirmed to be reasonable according to the analysis of cobalt, iron, and sulfur contents in oxidizing roasting ores. Calculation of the desulfurization rate is shown in Formula (1).

$$
\text { Desulfurization rate }=\left(\mathrm{Q}_{1} \times \alpha-\mathrm{Q}_{2} \times \beta\right) / \mathrm{Q}_{1} \times \alpha \times 100 \%
$$

Here, $Q_{1}$ is the weight of Co-bearing sulfur concentrate, $g$; $Q_{2}$ is the weight of oxidizing roasting ore, $g ; \alpha$ is the sulfur content of Co-bearing sulfur concentrate, $\%$; and $\beta$ is the sulfur content of oxidizing roasting ore, $\%$.

\subsection{Segregation Roasting-Magnetic Separation Test}

The Co-bearing concentrate, the chlorinating agent, and reducing agent were mixed and put into the roasting furnace. These mixtures were heated to a certain temperature $\left(400-1100{ }^{\circ} \mathrm{C}\right)$ under a neutral or weak reducing atmosphere, where the chlorinating agent was used to form volatile metal chlorides. For each magnetic test, segregation roasting ores were put into a $6.25 \mathrm{dm}^{3} \Phi 240 \times 90$ conical ball mill. The grinding density was set at $60 \%$. The pulp was then placed in a XCGS-13 ( $\Phi$ 50, Overall dimensions $1000 \times 800 \times 500 \mathrm{~mm}$ ) Davis Magnetic Tube (Jilin Exploration Machinery Plant, Shenyang China) with special magnetic field intensity. The products were filtered, dried, weighed, sampled, and tested for further evaluation based on the grade and recovery of cobalt and iron in magnetic products. The calculation formulas of cobalt recovery and iron recovery are shown in Formula (2).

$$
\text { Cobalt recovery }=\mathrm{Q}_{3} \times \beta_{1} / \mathrm{Q}_{0} \times \alpha_{1} \times 100 \% \text {, Iron recovery }=\mathrm{Q}_{4} \times \beta_{2} / \mathrm{Q}_{0} \times \alpha_{2} \times 100 \%
$$

Here, $Q_{3}$ is the weight of cobalt concentrate, $g$; $Q_{4}$ is the weight of iron concentrate, $g$; $Q_{0}$ is the weight of segregation roasting ores, $\mathrm{g} ; \beta_{1}$ is the cobalt grade of cobalt concentrate, $\% ; \beta_{2}$ is the iron grade of cobalt concentrate, $\%$; $\alpha_{1}$ is the cobalt grade of segregation roasting ores, $\%$; and $\alpha_{2}$ is the iron grade of segregation roasting ores, $\%$.

\subsection{Procedure}

The Co-bearing sulfur concentrate (mass of $100 \mathrm{~g}$ for each test) was placed in a tubular atmosphere furnace for oxidizing roasting. The reaction of the sulfide ore and oxygen was reversed to oxidize the ore, and the metals such as iron and cobalt were transformed into iron oxide and cobalt oxide. Oxidizing roasting ore (mass of $50 \mathrm{~g}$ for each test) after cooling, chlorinating agent, and coke were mixed and put into the muffle furnace for segregation chlorination roasting, which turned cobalt into a new metal cobalt mineral phase and iron into a new magnetite mineral phase. Metal cobalt is a ferromagnetic metal, and magnetite is a highly magnetic minerals. The specific magnetic susceptibility of cobalt metal is greater than the magnetic susceptibility of magnetite. Cobalt was recovered from segregation after grinding with a magnetic separator; iron was recovered from magnetic separation tailings by two-stage magnetic separation. The process of oxidizing roasting-segregation roasting-magnetic separation is shown in Figure 2. 


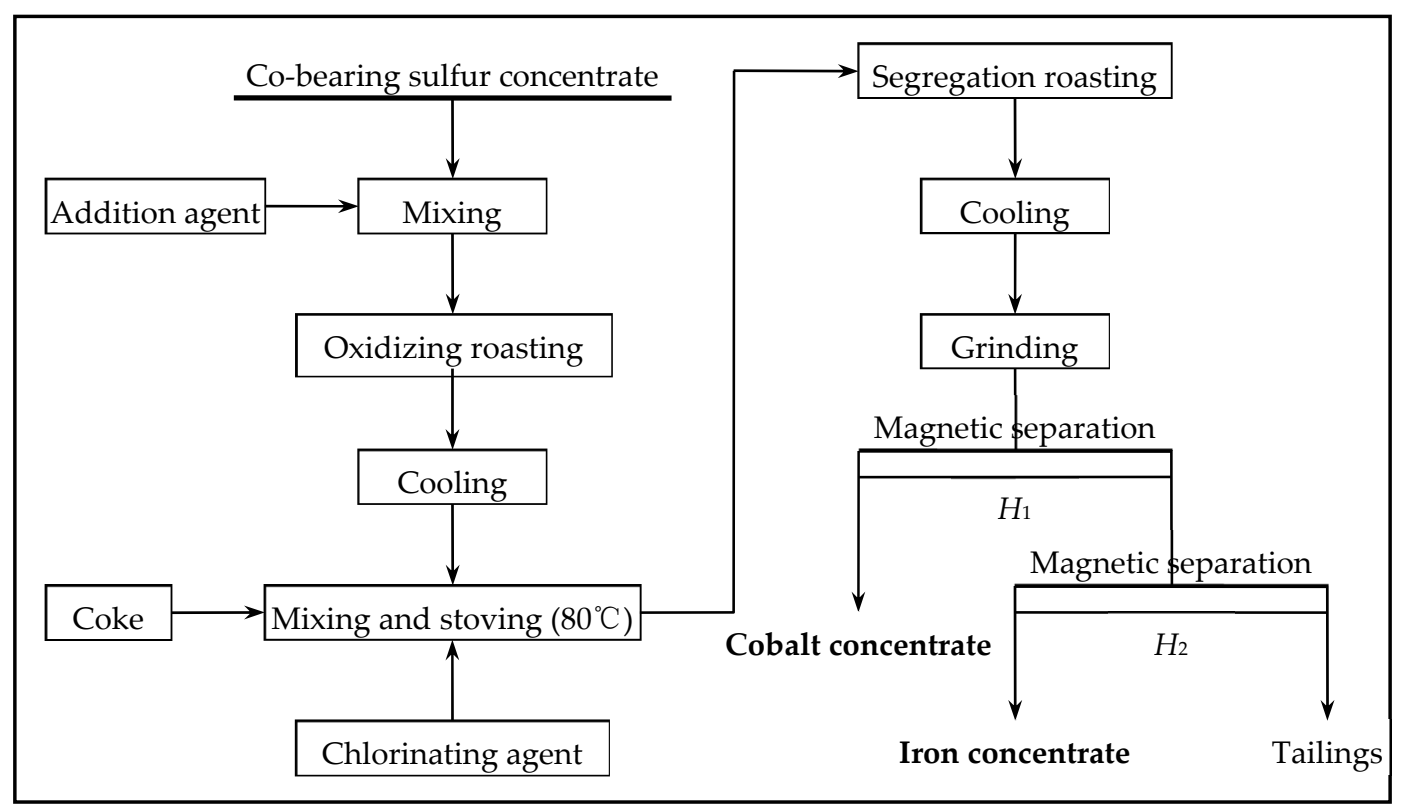

Figure 2. Scheme of the $\mathrm{Co}$ and Fe extraction process from Co-bearing sulfur concentrate.

\subsection{Analysis and Characterization}

The chemical composition of solid materials was analyzed by a Z-2000 atomic absorption spectrophotometer (Hitachi Co., Ltd. Tokyo, Japan); the direction grating was Zenier-tana type, 1800 lines/mm; the flash wavelength was $200 \mathrm{~nm}$, the wavelength range was 190 900 nm; and the automatic peak seeking setting and the spectral bandwidth was divided into 4 grades $(0.2,0.4,1.3$, and $2.6 \mathrm{~nm}$ ) to analyze the chemical composition of the mineral.

The phase compositions of solid substances (Co-bearing sulfur concentrate, oxidizing roasting ores, segregation roasting ores, cobalt concentrate, iron concentrate, and magnetic separation tailings) were analyzed by X-ray diffraction (XRD, X Pert pro, Panaco, The Netherlands). The microstructure of the solid products was observed by SEM (S440, Hirschmann Laborgerate GmbH \& Co. KG, Eberstadt, Germany) equipped with an energy-dispersive X-ray spectroscopy (EDS) detector (UItra55, CarlzeissNTS GmbH, Hirschmann Laborgerate GmbH \& Co. KG, Eberstadt, Germany).

\section{Results and Discussion}

\subsection{Removing Sulfur by Oxidizing Roasting}

\subsubsection{Effect of Roasting Temperature}

The roasting temperature test was conducted to investigate the influence of sulfur removal under the conditions employed, which were roasting time of $2 \mathrm{~h}$ and oxygen content of $80 \%$, and the results are shown in Figure 3.

In the oxidizing roasting process, the ignition point of pyrite was generally about $400{ }^{\circ} \mathrm{C}$, but the temperature fluctuated with the chemical composition of the material. When the temperature rose to $900^{\circ} \mathrm{C}$, the sulfur content in the oxidizing roasting ore was the lowest $(10.52 \%)$, and the desulfurization rate was $71.24 \%$. When the temperature increased from $900{ }^{\circ} \mathrm{C}$ to $1000{ }^{\circ} \mathrm{C}$, the sulfur content in the oxidized roasted ore increased to $14.36 \%$, and the desulfurization rate was $60.74 \%$. Therefore, the oxidizing roasting temperature of $900{ }^{\circ} \mathrm{C}$ was reasonable. 


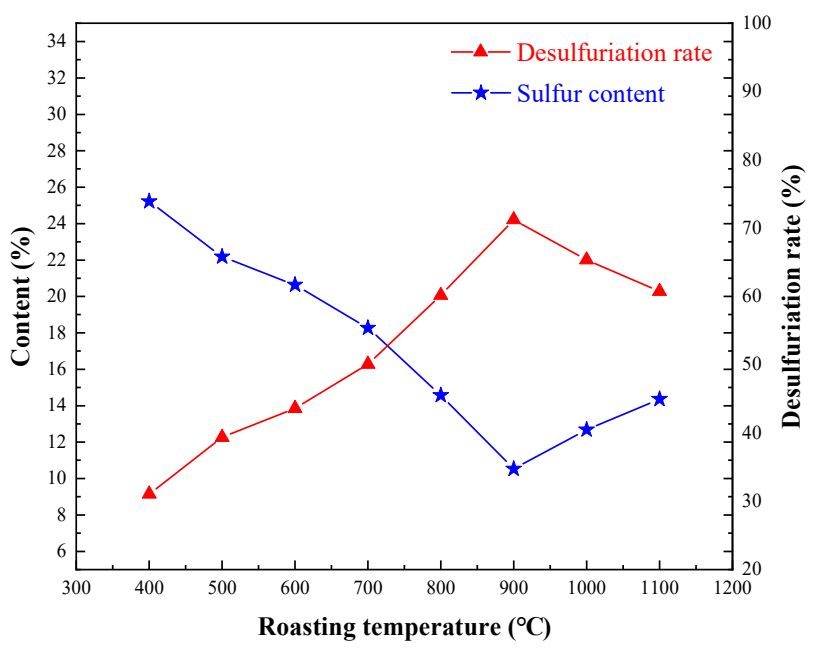

Figure 3. Effect of oxidizing roasting temperature on sulfur removal.

\subsubsection{Effect of Roasting Time}

Tests with different roasting times were carried out to investigate the influence of sulfur removal under the conditions employed, which were roasting temperature of $900{ }^{\circ} \mathrm{C}$ and oxygen content of $80 \%$, and the results are shown in Figure 4 .

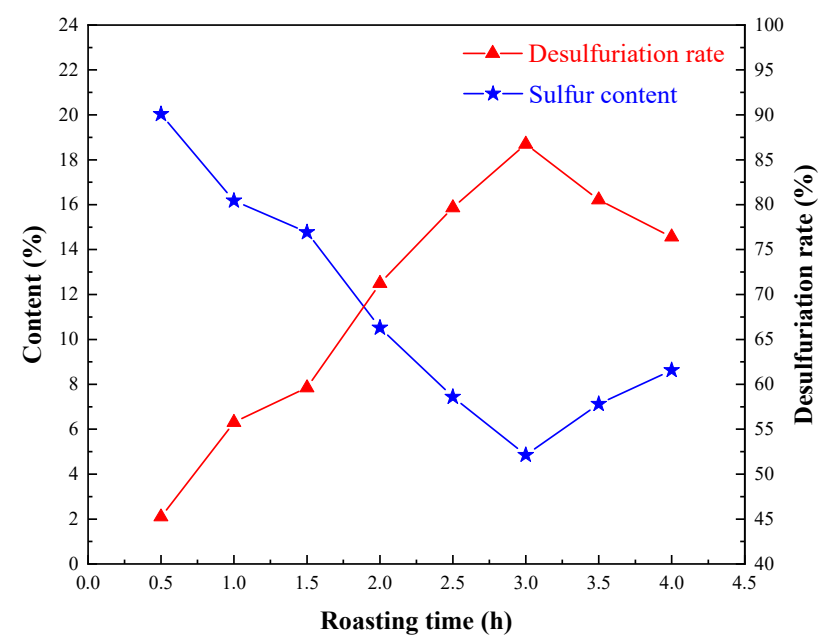

Figure 4. Effect of oxidizing roasting time on sulfur removal.

Prolonging the roasting time was conducive to the removal of sulfur, but when the roasting time was more than $3.0 \mathrm{~h}$, the sulfur content in the roasting ore increased regularly. Therefore, $3.0 \mathrm{~h}$ was suitable for oxidizing roasting, and $4.85 \%$ sulfur-bearing oxidizing roasting ore could be obtained with a desulfurization rate of $86.74 \%$.

\subsubsection{Effect of Roasting Atmosphere}

Tests under various atmospheric conditions were conducted to investigate the influence of sulfur removal under the conditions employed, which were roasting temperature of $900{ }^{\circ} \mathrm{C}$ and roasting time of $3.0 \mathrm{~h}$, and the results are shown in Figure 5.

It is known from Figure 5 that the increase in oxygen content had an obvious effect on the removal of sulfur. With the increase of oxygen content, the sulfur content in the oxidizing roasting ore decreased gradually and tended to be stable at 70\% oxygen or higher. This shows that the Co-bearing sulfur concentrate needs an oxygen-enriched atmosphere for oxidizing roasting. The oxygen content was $80 \%$, the sulfur content in the oxidizing roasting ore was $0.63 \%$, and the desulfurization rate was 
$98.28 \%$. Compared with the sulfur content in the Co-bearing sulfur concentrate, the desulfurization effect was remarkable. The sulfides effectively transformed into oxides, and favorable conditions were created for the separation and extraction of cobalt and iron.

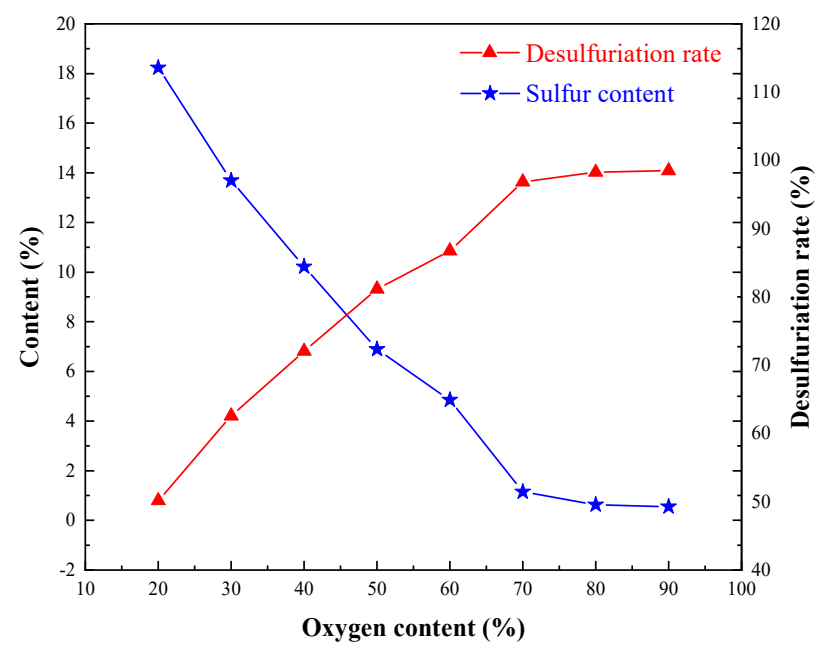

Figure 5. Effect of oxygen content on sulfur removal.

\subsubsection{Analysis and Characterization of Oxidizing Roasting Ores}

Repeated tests were conducted using the comprehensive conditions employed, which were Co-bearing sulfur concentrate mass of $500 \mathrm{~g}$, oxidizing roasting temperature of $900{ }^{\circ} \mathrm{C}$, oxidizing roasting time of $3.0 \mathrm{~h}$, and oxygen content of $80 \%$. Moreover, the multiple oxidizing roasting ore times were merged into a comprehensive sample for analysis and characterization, and cobalt and iron were extracted by magnetic separation of samples. The main chemical composition of oxidizing roasting ores is shown in Table 6, and the main minerals of oxidizing roasting ores by X-ray diffraction (XRD) are shown in Figure 6.

Table 6. Main chemical composition of oxidizing roasting ores (\%).

\begin{tabular}{ccccccccccc}
\hline $\mathrm{Fe}$ & $\mathrm{Co}$ & $\mathrm{S}$ & $\mathrm{CaO}$ & $\mathrm{MgO}$ & $\mathrm{Al}_{2} \mathrm{O}_{3}$ & $\mathrm{SiO}_{2}$ & $\mathrm{Mn}$ & $\mathrm{K}_{2} \mathrm{O}$ & $\mathrm{Na}_{2} \mathrm{O}$ & $\mathrm{TiO}_{2}$ \\
\hline 35.27 & 0.76 & 0.62 & 5.12 & 3.72 & 8.71 & 8.34 & 0.04 & 0.71 & 0.25 & 2.13 \\
\hline
\end{tabular}

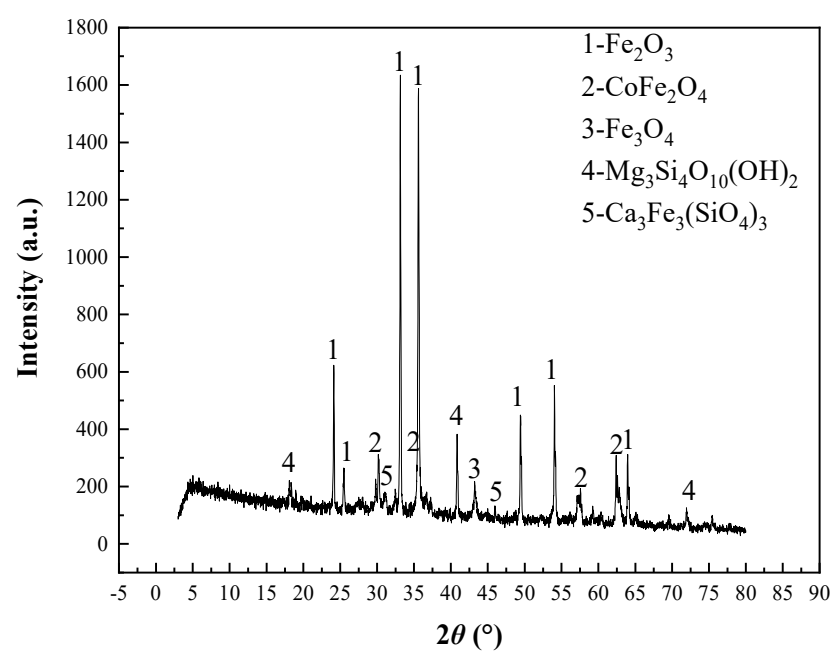

Figure 6. XRD diffractogram of oxidizing roasting ores. 
Results in Table 6 show that the sulfur content in the oxidizing roasting ore obtained from the repeated test under comprehensive conditions was $0.62 \%$, which is basically consistent with the desulfurization effect of the single-condition test and also shows that the obtained oxidizing roasting conditions are repeatable. XRD mineral composition showed that, after the oxidizing roasting of cobalt-bearing sulfur concentrate, cobalt changed from Co-pyrite and linneite to a $\mathrm{CoFe}_{2} \mathrm{O}_{4}$-dominated new cobalt mineral phase, and iron changed from pyrite to $\mathrm{Fe}_{2} \mathrm{O}_{3}$ and an $\mathrm{Fe}_{3} \mathrm{O}_{4}$-dominated new iron mineral phase. At the same time, new gangue mineral phases such as $\mathrm{Mg}_{3} \mathrm{Si}_{4} \mathrm{O}_{10}(\mathrm{OH})_{2}$ and $\mathrm{Ca}_{3} \mathrm{Fe}_{3}\left(\mathrm{SiO}_{4}\right)_{3}$ also appeared.

\subsection{Cobalt Extraction from Oxidizing Roasting Ores by Segregation Roasting-Magnetic Separation}

\subsubsection{Effect of Chlorinating Agent Dosage}

Calcium chloride and sodium chloride tests with varies dosages were conducted to investigate the influences of cobalt grade and recovery. The conditions employed were roasting temperature of $900{ }^{\circ} \mathrm{C}$, roasting time of $60 \mathrm{~min}$, coke dosage of $8 \%$, coke size of $<0.6 \mathrm{~mm}$, magnetic separation grinding fineness of $<60 \mu \mathrm{m}$ occupying $85 \%$, and magnetic separation field intensity $H_{1}=0.06 \mathrm{~T}$, and the results are shown in Figure 7.
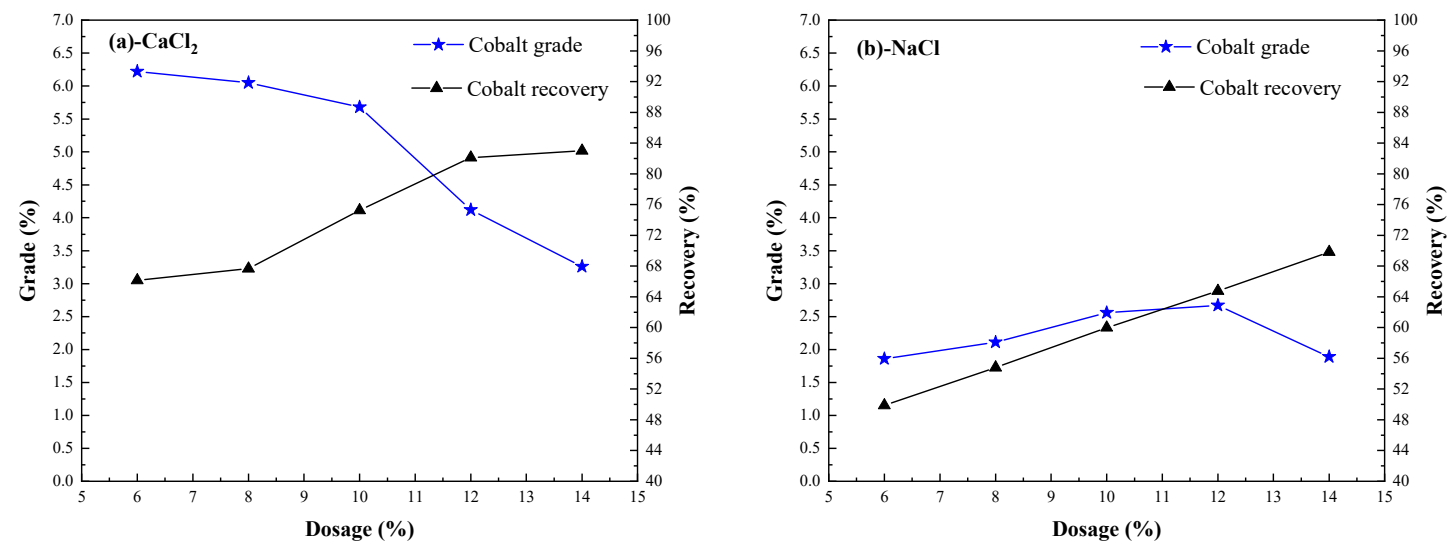

Figure 7. Effect of chlorinating agent dosage on cobalt extraction.

During the segregation roasting process, the chlorinator reacts with $\mathrm{SiO}_{2}, \mathrm{Al}_{2} \mathrm{O}_{3}$, and other acid oxides and $\mathrm{H}_{2} \mathrm{O}$ in the ore to generate hydrogen chloride gas. The valuable metal cobalt and iron react with hydrogen chloride to produce $\mathrm{CoCl}_{2}$ and $\mathrm{FeCl}_{2}$. Because $\mathrm{CoCl}_{2}$ and $\mathrm{FeCl}_{2}$ are unstable, they are easily reduced to metal particles by $\mathrm{H}_{2}$ and adsorb on the surface of coke; meanwhile, hydrogen chloride gas will react with its elements in chlorination, with too much or too little dosage, which will affect the separation and extraction of cobalt and iron. The grade and recovery of cobalt concentrate can be improved by increasing the amount of calcium chloride or sodium chloride [15]. When the amount of calcium chloride was $6 \%$, the highest cobalt grade was $6.22 \%$, but the lowest recovery was $66.14 \%$; when the amount of calcium chloride was $12 \%$, the highest recovery of cobalt was $82.11 \%$, and the cobalt grade was $4.12 \%$. When sodium chloride was used as the chlorinating agent, the grade of cobalt was lower than $3 \%$, and the recovery of cobalt was lower with the increase of dosage. The results showed that calcium chloride was suitable as chlorinating agent, taking into account cobalt grade and cobalt recovery, and the amount of calcium chloride was $12 \%$.

\subsubsection{Effect of Roasting Temperature}

Tests with different temperatures were conducted to investigate the influence of cobalt grade and recovery. The conditions employed were roasting time of $60 \mathrm{~min}$, calcium chloride dosage of $12 \%$, coke dosage of $8 \%$, coke size of $<0.6 \mathrm{~mm}$, magnetic separation grinding fineness of $<60 \mu \mathrm{m}$ occupying $85 \%$, and magnetic separation field intensity $H_{1}=0.06 \mathrm{~T}$, and the results are shown in Figure 8. 


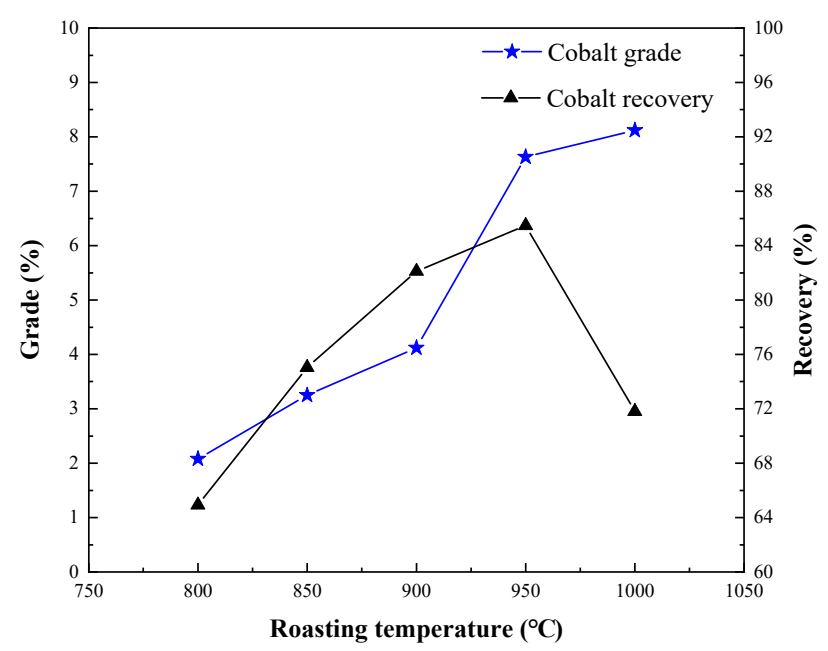

Figure 8. Effect of segregation roasting temperature on cobalt extraction.

Figure 8 shows that the roasting temperature was also one of the key factors to determine whether the separation process was going on. Raising the temperature is conducive to the reaction and accelerating the reaction rate. If the temperature is too low to reach the critical point of the chemical reaction of the ore, this will result in slow or difficult chemical reaction process [16,17]. With the increase of roasting temperature, the grade of cobalt increased, and the recovery of cobalt increased first and then decreased. When the temperature increased to $950{ }^{\circ} \mathrm{C}$, the grade of cobalt increased to $7.63 \%$, and the recovery rate of cobalt was $85.47 \%$; when the temperature increased to $1000{ }^{\circ} \mathrm{C}$, the grade of cobalt increased to $8.23 \%$, but the recovery rate of cobalt decreased to $71.81 \%$. At the same time, it was found that when the temperature of segregation roasting was $1000{ }^{\circ} \mathrm{C}$, the segregation roasting ore was in a melting state, and obvious metal particles appeared, so it was difficult to grind the material to a particle size less than $60 \mu \mathrm{m}$. Therefore, $950{ }^{\circ} \mathrm{C}$ was suitable for segregation roasting, and cobalt concentrate with cobalt grade of $7.63 \%$ and recovery of $85.47 \%$ could be obtained.

\subsubsection{Effect of Roasting Time}

Tests with different segregation roasting times were conducted to investigate the influence of cobalt grade and recovery. The conditions employed were roasting temperature of $950{ }^{\circ} \mathrm{C}$, calcium chloride dosage of $12 \%$, coke dosage of $8 \%$, coke size of $<0.6 \mathrm{~mm}$, magnetic separation grinding fineness of $<60 \mu \mathrm{m}$ occupying $85 \%$, and magnetic separation field intensity $H_{1}=0.06 \mathrm{~T}$, and the results are shown in Figure 9.

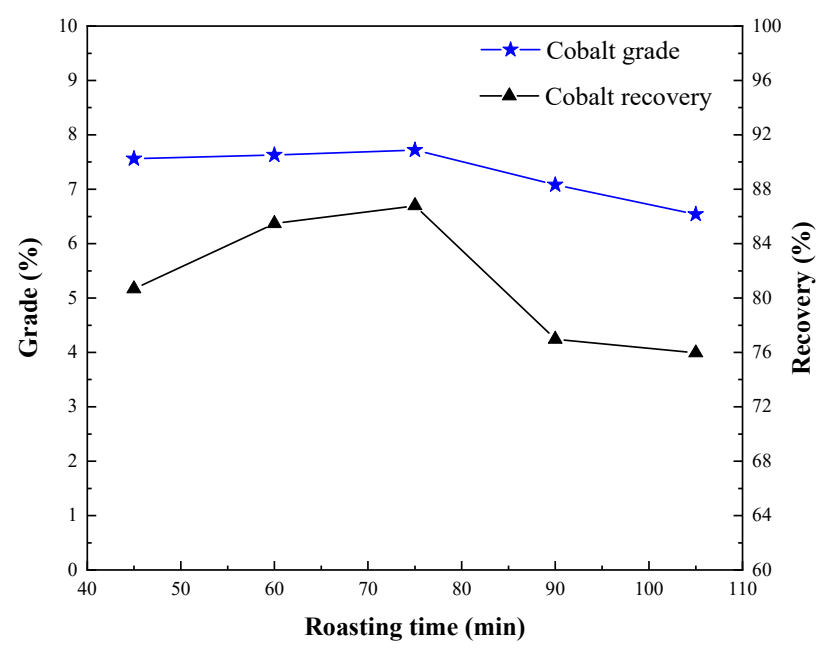

Figure 9. Effect of segregation roasting time on cobalt extraction. 
Results in Figure 9 show that the cobalt grade and recovery rate increased first and then decreased as time continued. The reason for this phenomenon is that the chemical reactions in the segregation roasting process are mainly divided into decomposition, chlorination, and reduction, but decomposition, chlorination, reduction, and other reactions are not only sequential chemical reactions, they are also complex phase changes. The segregation roasting time mainly affects the degree of chemical reaction in the process of segregation roasting. The longer the segregation roasting time, the more the chemical reaction is complete. However, the shorter the segregation roasting time, the less complete the effective chemical reaction is $[18,19]$. For this, it is difficult to achieve the ideal separation effect. Considering that the separation roasting time was $75 \mathrm{~min}$, a cobalt concentrate with a cobalt grade of $7.72 \%$ and a cobalt recovery of $86.79 \%$ could be obtained.

\subsubsection{Effect of Coke Dosage}

Tests with varies coke dosages were carried out to investigate the influence of cobalt grade and recovery. The conditions employed were roasting temperature of $950{ }^{\circ} \mathrm{C}$, roasting time of $75 \mathrm{~min}$, calcium chloride dosage of $12 \%$, coke size of $<0.6 \mathrm{~mm}$, magnetic separation grinding fineness of $<60 \mu \mathrm{m}$ occupying $85 \%$, and magnetic separation field intensity $H_{1}=0.06 \mathrm{~T}$, and the results are shown in Figure 10.

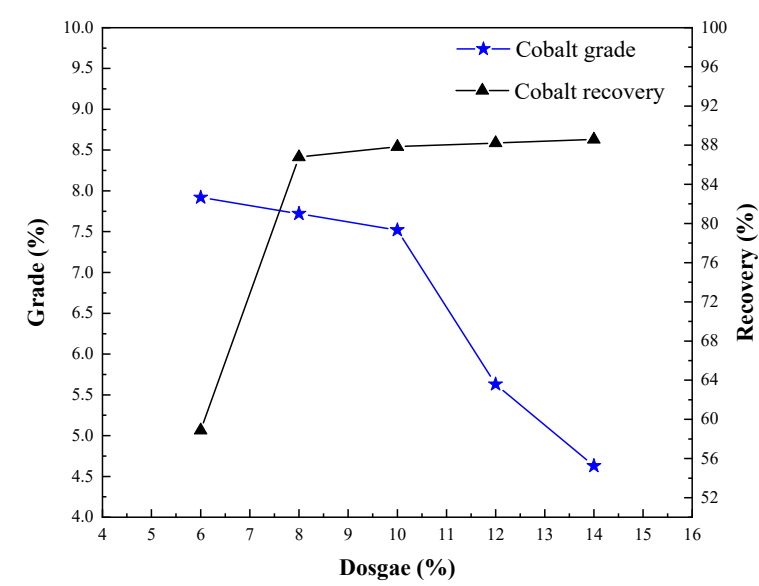

Figure 10. Effect of coke dosage on cobalt extraction.

Figure 10 reveals that the solid reducing agent was mainly used for coke, lignite, anthracite, bituminous coal, and charcoal, among which coke was most commonly used. Because of more impure elements in coal, this will produce certain ash and affect the product quality. Charcoal from wood is generally used for beneficiation or smelting of precious metals. When the amount of coke increased to $10 \%$, the highest cobalt grade was $7.52 \%$, and the recovery rate of cobalt was $87.85 \%$. When the amount of coke exceeded $10 \%$, the grade of cobalt decreased obviously, and the recovery rate of cobalt increased to a certain extent. Because coke is a reduction carrier for volatile metal chloride in the process of chlorination segregation roasting, and it adjusts the atmosphere of chlorination and segregation properly, too much or too little coke will affect the grade and recovery of cobalt. Therefore, it was reasonable to use $10 \%$ coke.

\subsubsection{Effect of Coke Size}

A coke size test was conducted to investigate its influence on cobalt grade and recovery. The conditions employed were oxidizing roasting ore mass of $50 \mathrm{~g}$, roasting temperature of 950 ${ }^{\circ} \mathrm{C}$, roasting time of $75 \mathrm{~min}$, calcium chloride dosage of $12 \%$, coke dosage of $10 \%$, magnetic separation grinding fineness of $<60 \mu \mathrm{m}$ occupying $85 \%$, and magnetic separation field intensity $H_{1}=0.06 \mathrm{~T}$, and the results are shown in Figure 11. 


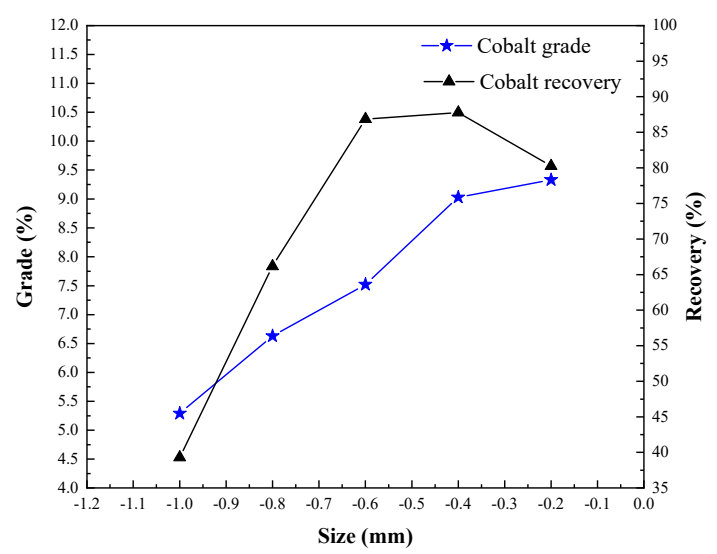

Figure 11. Effect of coke size on cobalt extraction.

The specific surface area $\left(a_{\mathrm{s}}=\mathrm{As} / \mathrm{m}\right)$ is an important index in measuring the adsorption capacity of coke. The smaller the coke particle size, the stronger its adsorption capacity. Figure 11 shows that with the decrease of coke particle size, the grade of cobalt increased, and the recovery of cobalt increased first and then decreased. In the process of segregation roasting, the reductant can adjust the atmosphere for chloride separation and absorb and reduce the volatile metal chloride $[19,20]$. Therefore, coke was used as the reducing agent and the carrier of adsorbing metal particles in the process of separation and roasting. Too much or too little coke is not conducive to the separation and extraction of cobalt. The size of coke was $<0.4 \mathrm{~mm}$, which was suitable to obtain a cobalt concentrate with a cobalt grade of $9.03 \%$ and a cobalt recovery of $87.77 \%$.

\subsubsection{Effect of Magnetic Separation Conditions of Segregation Roasting Ores}

The grinding fineness and magnetic field intensity are important factors that affect cobalt grade and cobalt recovery in the magnetic separation process of segregation roasting ores. Reasonable grinding fineness and magnetic field intensity are beneficial to improve the separation and extraction index of cobalt. Magnetic separation fineness grinding of segregation roasting ores was conducted to investigate its influence on cobalt grade and recovery, and the conditions employed were segregation roasting temperature of $950{ }^{\circ} \mathrm{C}$, segregation roasting time of $75 \mathrm{~min}$, calcium chloride dosage of $12 \%$, coke dosage of $10 \%$, coke size of $<0.4 \mathrm{~mm}$, and magnetic separation field intensity $H_{1}=0.06 \mathrm{~T}$, and the results are shown in Figure 12a.
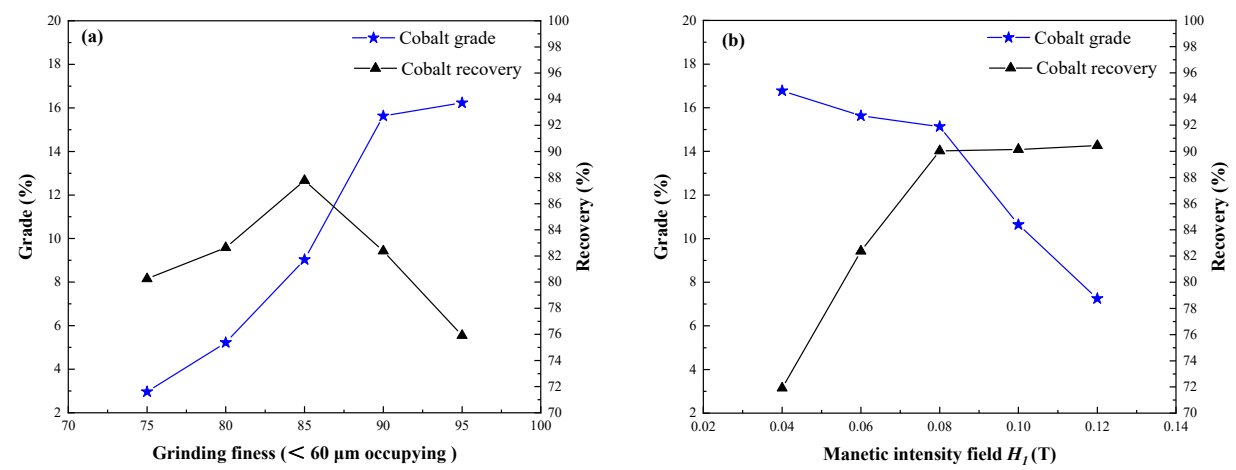

Figure 12. Effect of grinding fineness and magnetic intensity field on cobalt extraction: (a) Grinding fineness; (b) Magnetic intensity filed.

Grinding fineness is the key factor that reflects the degree of dissociation of the mineral monomer, and basic dissociation of the mineral is the primary factor to realize mineral separation. In the process of magnetic separation, it is beneficial to improve the cobalt grade of cobalt concentrate. Figure 12a shows that $90 \%$ of particles finer than $60 \mu \mathrm{m}$ were suitable for cobalt magnetic separation, and cobalt 
concentrate with a cobalt grade of $15.63 \%$ and cobalt recovery of $82.38 \%$ were obtained. If the grinding fineness is too high, the recovery rate of cobalt concentrate decreases significantly, and the particle size becomes smaller.

In the process of magnetic separation, the effect of external forces becomes more obvious. To improve the magnetic separation index, the field intensity of magnetic separation needs to be changed. A magnetic separation field intensity test for the segregation roasting ores was conducted to investigate the influence of cobalt grade and recovery. The conditions employed were oxidizing roasting ore mass of $50 \mathrm{~g}$, segregation roasting temperature of $950{ }^{\circ} \mathrm{C}$, segregation roasting time of $75 \mathrm{~min}$, calcium chloride dosage of $12 \%$, coke dosage of $10 \%$, coke size of $<0.4 \mathrm{~mm}$, and magnetic separation grinding fineness of $<60 \mu \mathrm{m}$ occupying $90 \%$, and the results are shown in Figure 12b.

With the increase of magnetic field intensity, the grade of cobalt decreased and the recovery of cobalt increased. In the process of magnetic separation, different magnetic minerals received the combined action of magnetic field force, gravity, medium resistance, and other external mechanical forces in the magnetic field. When the magnetic field force of the mineral particles is greater than the mechanical external force, they will enter the magnetic products and become the concentrate; otherwise, they will enter the non-magnetic products and become the tailings. Therefore, the magnetic field intensity $H_{1}=0.08 \mathrm{~T}$ was suitable, and the cobalt concentrate with cobalt grade of $15.13 \%$ and cobalt recovery of $90.04 \%$ was obtained.

\subsection{Iron Extraction from Cobalt Magnetic Separation Tailings by Magnetic Separation}

The magnetism of new cobalt minerals and iron minerals was different in segregation roasting ores, and the effective extraction index of cobalt was obtained from segregation roasting ores by one-stage magnetic separation. Extraction of iron from cobalt magnetic separation tailings was conducted by changing the magnetic field intensity using second-stage magnetic separation. Different magnetic separation field intensity $\left(\mathrm{H}_{2}\right)$ tests were investigated, and the test results are shown in Figure 13.

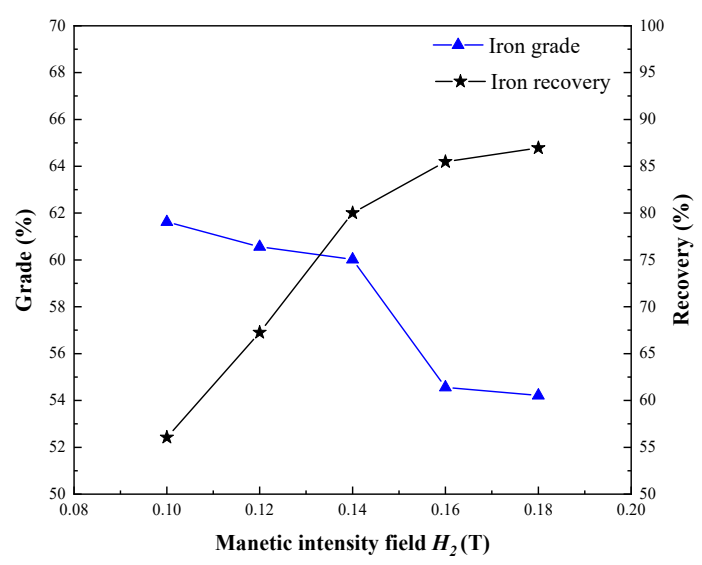

Figure 13. Effect of magnetic intensity field on iron extraction.

The iron recovery rate of iron concentrate improved by increasing the magnetic field intensity, and the iron grade in Figure 13 reveals a regular increase as the magnetic field intensity decreased. The existing iron and steel enterprises require that the iron grade of iron and steel concentrate is more than $55 \%$, so the magnetic field intensity is $\mathrm{H}_{2}=0.14 \mathrm{~T}$, which is suitable to obtain iron concentrate with iron grade of $60.02 \%$ and iron recovery of $80.01 \%$.

\subsection{The Entire Co, Fe Extraction Process Test}

The entire process of cobalt and iron extraction was conducted to investigate the influence of cobalt grade and recovery, and the conditions employed were oxidizing roasting temperature of $900{ }^{\circ} \mathrm{C}$, oxidizing roasting time of $3.0 \mathrm{~h}$, oxygen content of $80 \%$, segregation roasting temperature of $950{ }^{\circ} \mathrm{C}$, 
segregation roasting time of $75 \mathrm{~min}$, calcium chloride dosage of $12 \%$, coke dosage of $10 \%$, coke size of $<0.4 \mathrm{~mm}$, magnetic separation grinding fineness of $<60 \mu \mathrm{m}$ occupying $90 \%$, cobalt magnetic separation field intensity $H_{1}=0.08 \mathrm{~T}$, and iron magnetic separation field intensity $H_{2}=0.14 \mathrm{~T}$. The results are shown in Tables 7-9.

Table 7. Results of oxidizing roasting-segregation roasting-magnetic separation (\%).

\begin{tabular}{cccccc}
\hline \multirow{2}{*}{ Products } & \multirow{2}{*}{ Productivity } & \multicolumn{2}{c}{ Grade } & \multicolumn{2}{c}{ Recovery } \\
\cline { 3 - 6 } & & Co & Fe & Co & Fe \\
\hline Cobalt concentrate & 4.08 & 15.15 & 71.22 & 90.81 & 8.74 \\
Iron concentrate & 42.21 & 0.11 & 60.06 & 6.82 & 76.23 \\
Tailings & 53.71 & 0.03 & 9.31 & 2.37 & 15.03 \\
Totals & 100.00 & 0.68 & 33.26 & 100.00 & 100.00 \\
\hline
\end{tabular}

Table 8. Main chemical composition of cobalt concentrate (\%).

\begin{tabular}{cccccccc}
\hline $\mathrm{Co}$ & $\mathrm{Fe}$ & $\mathrm{S}$ & $\mathrm{CaO}$ & $\mathrm{MgO}$ & $\mathrm{Al}_{2} \mathrm{O}_{3}$ & $\mathrm{SiO}_{2}$ & $\mathrm{Mn}$ \\
\hline 15.15 & 71.22 & 0.04 & 1.22 & 0.36 & 0.55 & 3.12 & 0.002 \\
\hline
\end{tabular}

Table 9. Main chemical composition of iron concentrate (\%).

\begin{tabular}{cccccccc}
\hline $\mathrm{Fe}$ & $\mathrm{Co}$ & $\mathrm{S}$ & $\mathrm{CaO}$ & $\mathbf{M g O}$ & $\mathrm{Al}_{2} \mathrm{O}_{3}$ & $\mathrm{SiO}_{2}$ & $\mathrm{Mn}$ \\
\hline 60.06 & 0.11 & 0.05 & 8.03 & 4.11 & 0.56 & 6.56 & 0.006 \\
\hline
\end{tabular}

Results in Tables 7-9 show the extraction effects of cobalt and iron from Co-bearing sulfur concentrate in the Panxi area using the oxidizing roasting-segregation roasting-magnetic separation process. Cobalt concentrate with Co grade of $15.15 \%$, Fe content of $71.22 \%$, and cobalt recovery of $90.81 \%$ as well as iron concentrate with Fe grade of $60.06 \%$, Co content of $0.11 \%$, and iron recovery of $76.23 \%$ were obtained. The content of harmful elemental sulfur in the iron concentrate was also lower, which met the product quality requirements for highly efficient extraction and separation of valuable metal cobalt and iron. Sulfur was produced in the form of $\mathrm{SO}_{2}$ in the oxidizing roasting process, which can be used as an important raw material for the preparation of sulfuric acid.

\subsection{Cobalt and Iron Phase Transformation in the Segregation Roasting Process}

Analysis and characterization of segregation roasting ores, cobalt concentrate, and iron concentrate were investigated by X-ray diffraction (XRD), scanning electron microscopy (SEM), and energy spectroscopy (EDS) to find out the mineral phase evolution of cobalt minerals and iron minerals. XRD phase analysis results of cobalt concentrate and iron concentrate are shown in Figure 14. SEM and EDS images of cobalt and iron minerals are shown in Figure 15.

According to the existing kinetic mechanism, the separation roasting stage can be divided into five stages. (1) Solid phase sintering reaction stage: oxidizing roasting, chlorinating agent, and reducing agent are dried at low temperature and then put into the baking furnace. Before chlorination segregation roasting, the pellet sintering process is shown, which is actually a series of solid-phase sintering reactions. (2) Decomposition stage: this stage is mainly the decomposition reaction of calcium chloride to form hydrogen chloride gas with strong activity, The reaction of the reducing agent and water vapor produces hydrogen and carbon monoxide. A catalyst promotes the positive reaction direction of the separation process to proceed rapidly. (3) Gas-solid reaction stage: the ore is still in the solid state because the separation roasting temperature is at $950^{\circ} \mathrm{C}$, which is not high enough for the softening point is more of a gas-solid reaction. Hydrogen chloride gas with strong volatilization activity reacts rapidly with metal in ores to form volatile chloride, and the decomposition pressure of various metal chlorides is different. The promotion and inhibition of catalysts and promoters can improve the volatilization rate of the metal cobalt target. (4) Reduction adsorption stage: the formation of volatile 
metal chlorides through the gas-solid phase reaction forms a strong physical and chemical adsorption on the surface of the reducing agent. The decomposition pressures of various volatile metal chlorides are high and low, and the corresponding double effects of adsorption and reduction on the surface of the reducing agent form fine metal particles. (5) New phase formation stage: the size of metal particles formed in the early stage of new phase formation is very fine, the corresponding specific surface area is large, and the fine particles themselves have strong adsorption, which belongs to the thermodynamic instability system. Then, the "metal core" in the early stage makes the metal particles formed in the later stage continuously rearrange and pile up, and the crystal particles grow, finally forming a certain size of metal particle compounds [21-25].

After the separation roasting of oxidized roasted ore, cobalt changes from $\mathrm{CoFe}_{2} \mathrm{O}_{4}$ to a new cobalt mineral phase dominated by a [Co] Fe solid solution; iron changes from $\mathrm{Fe}_{2} \mathrm{O}_{3}$ to a new iron mineral phase dominated by metal $\mathrm{Fe}$ and $\mathrm{Fe}_{3} \mathrm{O}_{4}$. Cobalt and iron belong to ferromagnetic metals. Magnetite belongs to strong magnetic minerals, and their specific magnetization coefficients are different to some extent. The main minerals in the cobalt concentrate obtained from the separation roasting ore after grinding were $\mathrm{Fe},[\mathrm{Co}] \mathrm{Fe}, \mathrm{Fe}_{3} \mathrm{O}_{4}$, and $\mathrm{SiO}_{2}$; the main minerals in the iron concentrate obtained from the second-stage magnetic separation were $\mathrm{Fe}_{3} \mathrm{O}_{4}, \mathrm{FeO}, \mathrm{Ca}_{2} \mathrm{Si}_{2} \mathrm{O}_{4}$, and $\mathrm{Ca}_{2} \mathrm{Al}_{2} \mathrm{O}_{4}$. In the process of magnetic separation, a small amount of gangue minerals such as $\mathrm{SiO}_{2}, \mathrm{Ca}_{2} \mathrm{Si}_{2} \mathrm{O}_{4}$, and $\mathrm{Ca}_{2} \mathrm{Al}_{2} \mathrm{O}_{4}$ entered into cobalt concentrate and iron concentrate as a result of mechanical entrainment. Therefore, there are many complex phase changes in the segregation roasting process. Combined with the analysis results, the possible chemical reactions in the segregation roasting process are shown in Equations (3)-(10).

$$
\begin{aligned}
& \mathrm{CaCl}_{2}+\mathrm{xSiO}_{2}+\mathrm{H}_{2} \mathrm{O} \rightarrow \mathrm{CaO} \cdot \times \mathrm{SiO}_{2}+\mathrm{HCl} \\
& \mathrm{CaCl}_{2}+\mathrm{Al}_{2} \mathrm{O}_{3} \cdot 2 \mathrm{SiO}_{2} \cdot 2 \mathrm{H}_{2} \mathrm{O} \rightarrow(\mathrm{CaO})_{2} \cdot \mathrm{Al}_{2} \mathrm{O}_{3} \cdot 2 \mathrm{SiO}_{2}+\mathrm{HCl} \\
& \mathrm{C}+\mathrm{H}_{2} \mathrm{O} \rightarrow \mathrm{CO}+\mathrm{H}_{2} \\
& 3 \mathrm{Fe}_{2} \mathrm{O}_{3}+\mathrm{CO} \rightarrow 2 \mathrm{Fe}_{3} \mathrm{O}_{4}+\mathrm{CO}_{2} \\
& \mathrm{CoFe} \mathrm{O}_{4}+6 \mathrm{HCl} \rightarrow \mathrm{CoCl}_{2}+2 \mathrm{FeCl}_{3}+3 \mathrm{H}_{2} \mathrm{O} \\
& \mathrm{CoCl}_{2}+\mathrm{H}_{2} \rightarrow \mathrm{Co}+\mathrm{HCl} \\
& \mathrm{FeCl}_{3}+3 \mathrm{H}_{2} \rightarrow 2 \mathrm{Fe}+6 \mathrm{HCl} \\
& 2 \mathrm{Co}+2 \mathrm{FeCl}_{3}+3 \mathrm{H}_{2} \rightarrow 2[\mathrm{Co}] \mathrm{Fe}+6 \mathrm{HCl}
\end{aligned}
$$

In the system, the relationship between the difficulties in the reduction of iron cobalt metal chloride is $\mathrm{FeCl}_{3}<\mathrm{CoCl}_{2}$, and cobalt is a kind of iron-soluble oxide. $\mathrm{FeCl}_{3}$ itself is a kind of chlorinating agent, promoting the chlorination and segregation of cobalt, and forms the solid solution of [Co] Fe.
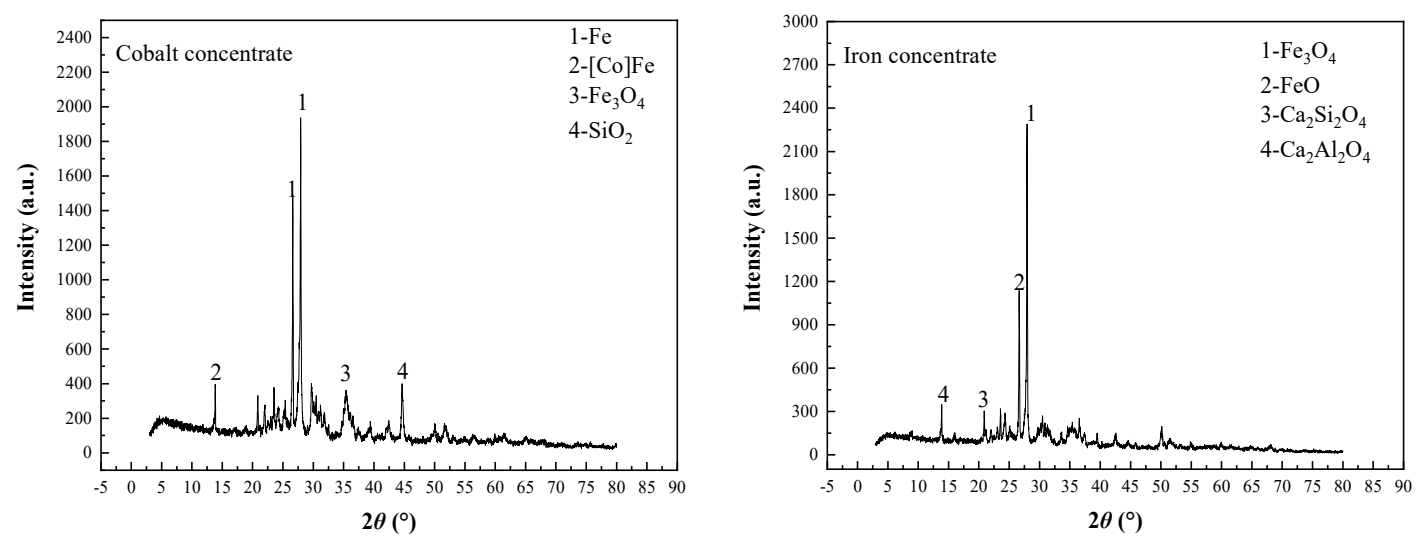

Figure 14. XRD diffractogram of the cobalt concentrate and iron concentrate. 

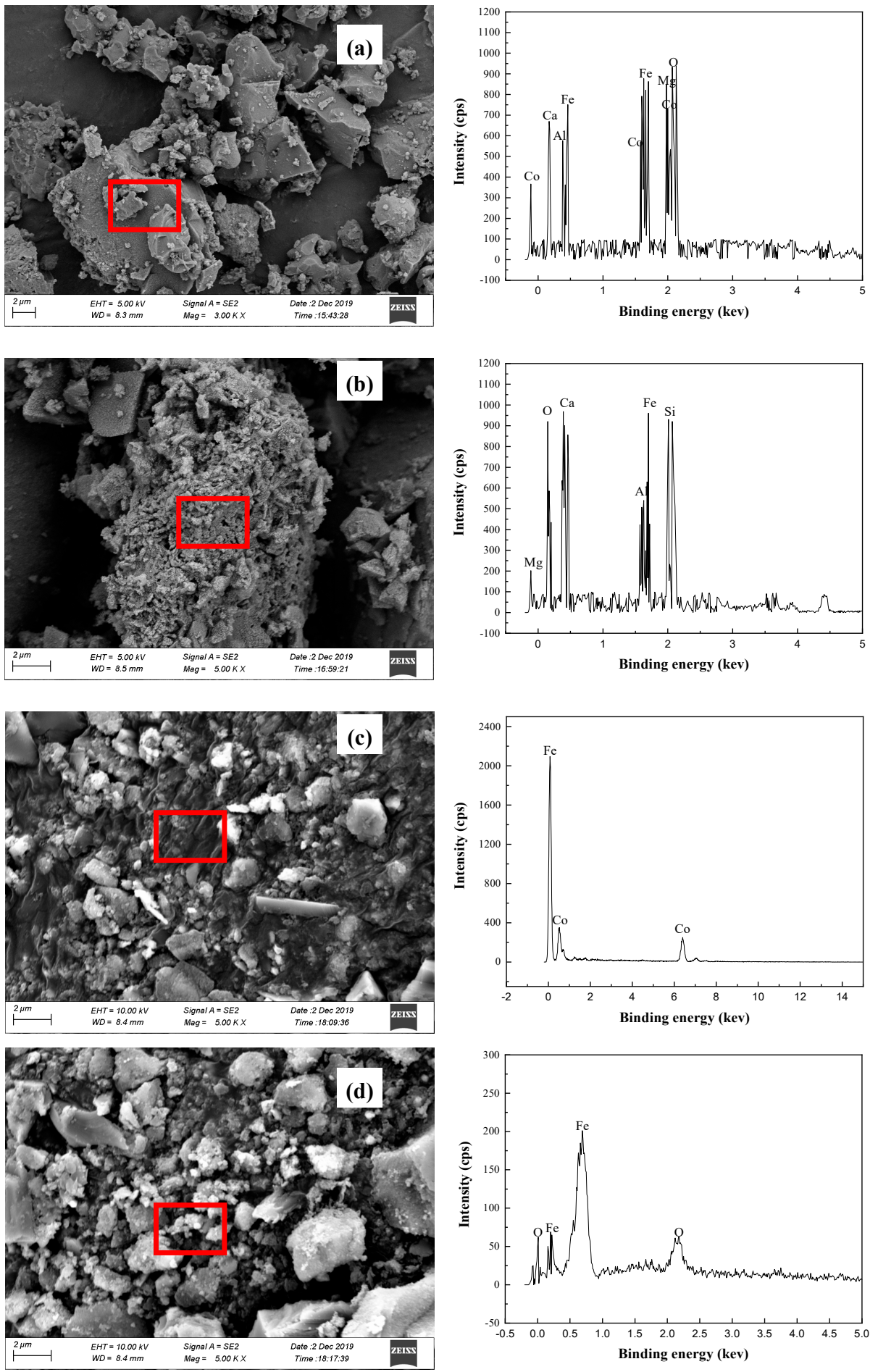

Figure 15. SEM and EDS images (a-segregation roasting ores; $\mathbf{b}$-tailings; $\mathbf{c}$ - cobalt concentrate; d-iron concentrate).

\section{Conclusions}

(1) The refractory Co-bearing sulfur concentrate sample was collected from a V-Ti magnetite dressing plant by flotation in the Panzhihua area of China, and the Co-bearing sulfur concentrate contained Co $0.68 \%$, Fe $33.26 \%$, and S $36.58 \%$. Pyrite was the main sulfide ore; Co-pyrite and linneite were Co-bearing minerals; gangue minerals were mica, chlorite, feldspar, calcite, etc., in Co-bearing concentrate. 
(2) A new process of oxidizing roasting-segregation roasting-magnetic separation is used to process the complex Co-bearing sulfur concentrate. The cobalt concentrate with Co of $15.15 \%$, Fe $71.22 \%$, and cobalt recovery of $90.81 \%$ as well as iron concentrate with Fe of $60.06 \%$, Co of $0.11 \%$, and iron recovery of $76.23 \%$ were obtained under the comprehensive conditions of oxidizing roasting temperature of $900{ }^{\circ} \mathrm{C}$, oxidizing roasting time of $3.0 \mathrm{~h}$, oxygen content of $80 \%$, segregation roasting time of $950^{\circ} \mathrm{C}$, segregation roasting time of $75 \mathrm{~min}$, calcium chloride dosage of $12 \%$, coke dosage of $10 \%$, coke size of $<0.4 \mathrm{~mm}$, magnetic separation grinding fineness of $<60 \mu \mathrm{m}$ occupying $90 \%$, cobalt magnetic separation magnetic field intensity of $H_{1}=0.08 \mathrm{~T}$, and iron magnetic separation intensity of $\mathrm{H}_{2}=0.14 \mathrm{~T}$. Extraction of cobalt and iron is obvious.

(3) The results of cobalt and iron phase transformations show that cobalt is transformed from Co-pyrite and linneite to a $\mathrm{Co}_{2} \mathrm{FeO}_{4}$-dominated new cobalt mineral phase. Iron is transformed from pyrite to $\mathrm{Fe}_{2} \mathrm{O}_{3}$ and an $\mathrm{Fe}_{3} \mathrm{O}_{4}$-dominated new iron mineral phase after oxidizing roasting. Sulfur is produced in the form of $\mathrm{SO}_{2}$ after oxidizing roasting; cobalt changed from $\mathrm{CoFe}_{2} \mathrm{O}_{4}$ to a new cobalt mineral phase dominated by [Co]Fe solid solution. Iron changed from $\mathrm{Fe}_{2} \mathrm{O}_{3}$ to a new iron mineral phase dominated by metal $\mathrm{Fe}$ and $\mathrm{Fe}_{3} \mathrm{O}_{4}$ after segregation roasting.

(4) SEM, EDS, and XRD analyses of segregation roasting ores, cobalt concentrate, and iron concentrate show that the main minerals in cobalt concentrate are $\mathrm{Fe},[\mathrm{Co}] \mathrm{Fe}$, and a small amount of $\mathrm{Fe}_{3} \mathrm{O}_{4}$; the main minerals in iron concentrate are $\mathrm{Fe}_{3} \mathrm{O}_{4}$ and $\mathrm{FeO}$; and there was a small amount of gangue minerals such as $\mathrm{SiO}_{2}, \mathrm{Ca}_{2} \mathrm{Si}_{2} \mathrm{O}_{4}$, and $\mathrm{Ca}_{2} \mathrm{Al}_{2} \mathrm{O}_{4}$ in the cobalt concentrate and iron concentrate because of mechanical entrainment.

Author Contributions: This is a joint work of the two authors; each author was in charge of their expertise and capability: J.X. for writing, formal analysis, and original draft preparation; Y.Z. for conceptualization, validation, methodology, and investigation. All authors have read and agreed to the published version of the manuscript.

Funding: This work was supported by the Sichuan Science and Technology Program (Grant Nos.2019FS0451 and Nos.2018FZ0092); Key Laboratory of Sichuan Province for Comprehensive Utilization of Vanadium and Titanium Resources Foundation (2018FTSZ35); China Geological Big Survey (Grant No. DD20190694).

Conflicts of Interest: The authors declare no conflict of interest. The funders had no role in the design, analyses, and interpretation of any data of the study.

\section{References}

1. Gulley, A.L.; Nassar, N.T.; Xun, S. China, the United States, and competition for resources that enable emerging technologies. Proc. Natl. Acad. Sci. USA 2018, 115, 4111-4115. [CrossRef] [PubMed]

2. Yang, H.P.; Wang, W. Global Cobalt Resources Status and Exploitation Trends. Conserv. Util. Miner. Resour. 2019, 39, 41-49. (In Chinese)

3. Aleksandrov, P.V.; Medvedev, A.S.; Kadirov, A.A.; Imideev, V.A. Processing molybdenum concentrates using low-temperature oxidizing-chlorinating roasting. Russ. J. Non Ferr. Met. 2014, 55, 114-119. [CrossRef]

4. Aracena, A.; Jerez, O.; Ortiz, R.; Morales, J. Pyrite oxidation kinetics in an oxygen-nitrogen atmosphere at temperatures from 400 to $500{ }^{\circ} \mathrm{C}$. Can. Metall. Q. 2016, 55, 195-201. [CrossRef]

5. Aydin, F.; Ziyadanogullari, R. Separation of copper, cobalt and iron in solution obtained from copper ore. Asian J. Chem. 2007, 19, 5537.

6. Biswas, S.; Dey, R.; Mukherjee, S.; Banerjee, P.C. Bioleaching of nickel and cobalt from lateritic chromite overburden using the culture filtrate of Aspergillus niger. Appl. Biochem. Biotechnol. 2013, 170, 1547-1559. [CrossRef]

7. Cui, F.; Mu, W.; Wang, S.; Xin, H.; Xu, Q.; Zhai, Y.; Luo, S. Sodium sulfate activation mechanism on co-sulfating roasting to nickel-copper sulfide concentrate in metal extractions, microtopography and kinetics. Miner. Eng. 2018, 123, 104-116. [CrossRef]

8. Cui, F.; Mu, W.; Wang, S.; Xin, H.; Shen, H.; Xu, Q.; Luo, S. Synchronous extractions of nickel, copper, and cobalt by selective chlorinating roasting and water leaching to low-grade nickel-copper matte. Sep. Purif. Technol. 2018, 195, 149-162. [CrossRef]

9. Erust, C.; Akcil, A. Copper and cobalt recovery from pyrite ashes of a sulphuric acid plant. Waste Manag. Res. 2016, 34, 527-533. [CrossRef] 
10. Xiao, J.H.; Zhang, Y.S. Recovering Cobalt and Sulfur in Low Grade Co-bearing V-Ti Magnetite Tailings Using Flotation Process. Processes 2019, 7, 536. [CrossRef]

11. Morcali, M.H.; Khajavi, L.T.; Dreisinger, D.B. Extraction of nickel and cobalt from nickeliferous limonitic laterite ore using borax containing slags. Int. J. Miner. Process. 2017, 167, 27-34. [CrossRef]

12. Wang, W.; Zhang, Y.; Liu, X.; Xu, S. A simplified process for recovery of $\mathrm{Li}$ and Co from spent $\mathrm{LiCoO}_{2}$ cathode using Al foil as the in-situ reductant. ACS Sustain. Chem. Eng. 2019, 14, 12222. [CrossRef]

13. Zhang, Y.; Li, Q.; Liu, X.; Xu, B.; Yang, Y.; Jiang, T. A Thermodynamic Analysis on the Roasting of Pyrite. Minerals 2019, 9, 220. [CrossRef]

14. Zhang, M.; Zhu, G.; Zhao, Y.; Feng, X. A study of recovery of copper and cobalt from copper-cobalt oxide ores by ammonium salt roasting. Hydrometallurgy 2012, 129, 140-144. [CrossRef]

15. Ding, W.; Xiao, J.H.; Peng, Y.; Shen, S.Y.; Chen, T. Iron Extraction from Red Mud using Roasting with Sodium Salt. Miner. Process. Extr. Metall. Rev. 2019. [CrossRef]

16. Güntner, J.; Hammerschmidt, J. Sulphating roasting of copper-cobalt concentrates. J. South. Afr. Inst. Min. Metall. 2012, 112, 455-460.

17. Han, P.W.; Xiao, L.; Wang, Y.L.; Lu, Y.G.; Ye, S.F. Cobalt Recovery by the Chlorination-Volatilization Method. Metall. Mater. Trans. B 2019, 50, 1128-1133. [CrossRef]

18. Zhao, Q.; Xue, J.; Chen, W. A Novel Self-Magnetizing Roasting Process for Recovering Fe from Low-Grade Pyrite Cinder and Blast Furnace Sludge. Trans. Indian Inst. Metals 2019, 72, 2547-2556. [CrossRef]

19. Xiao, J.H.; Ding, W.; Peng, Y.; Wu, Q.; Chen, Z.Q.; Wang, Z.; Peng, T.F. Upgrading iron and removing phosphorus of high phosphorus Oolitic iron ore by segregation roasting with Calcium chloride and Calcium hypochlorite. J. Min. Metall. Sect. B Metall. 2019, 55, 305-314. [CrossRef]

20. Zhang, G.F.; Yang, Q.R.; Yang, Y.D.; Wu, P.; McLean, A. Recovery of iron from waste slag of pyrite processing using reduction roasting magnetic separation method. Can. Metall. Q. 2013, 52, 153-159. [CrossRef]

21. Zhou, Y.; Xu, P.; Cheng, H.; Liu, Q. Thermal phase transition of pyrite from coal. J. Therm. Anal. Calorim. 2018, 134, 2391-2396. [CrossRef]

22. Zhang, G.F.; Shi, Z.; Yan, P.; Gao, L. Study on separation of iron from waste slag of pyrite processing. Sep. Sci. Technol. 2015, 50, 292-298. [CrossRef]

23. Jin, J.; Han, Y.; Li, H.; Huai, Y.; Peng, Y.; Gu, X.; Yang, W. Mineral phase and structure changes during roasting of fine-grained carbonaceous gold ores and their effects on gold leaching efficiency. Chin. J. Chem. Eng. 2019, 27, 1184-1190. [CrossRef]

24. Zhang, X.; Liu, F.; Xue, X.; Jiang, T. Effects of microwave and conventional blank roasting on oxidation behavior, microstructure and surface morphology of vanadium slag with high chromium content. J. Alloys Compd. 2016, 686, 356-365. [CrossRef]

25. Ilyas, S.; Srivastava, R.R.; Kim, H.; Ilyas, N.; Sattar, R. Extraction of nickel and cobalt from a laterite ore using the carbothermic reduction roasting-ammoniacal leaching process. Sep. Purif. Technol. 2020, 32, 115971. [CrossRef]

(C) 2020 by the authors. Licensee MDPI, Basel, Switzerland. This article is an open access article distributed under the terms and conditions of the Creative Commons Attribution (CC BY) license (http://creativecommons.org/licenses/by/4.0/). 